\title{
Studies on the Mechanism of Phagocytosis. I. Effect of Electric Surface Charge on Phagocytic Activity of Macrophages for Fixed Red Cells
}

\author{
Hiroshi Nagura, Junpei Asai and Kiyohide Kojima \\ Department of Pathology, Nagoya University School of Medicine, Nagoya 466, \\ and Department of Oncological Pathology, Cancer Research Institute, Nara \\ Medical University, Nara 634, Japan
}

\begin{abstract}
The relationship was examined between in vitro peritoneal macrophage phagocytosis of glutaraldehyde-treated sheep red cells (GRCs) and the electric surface charge density of the cells. A low ionic strength produced a significant increase in the negative charge of the macrophage and GRC surfaces, and this was accompanied with a reduction in macrophage phagocytic activity. Treatment of cells with protamine sulfate reduced the negative surface charge of both macrophages and GRCs. This protamine sulfate treatment resulted in an increase of macrophage phagocytic activity. Furthermore, the macrophage phagocytic activity decreased linearly with an increase in the product of the negative charge density on the surfaces of both macrophages and GRCs. These results suggest that the magnitude of the electrostatic repulsion force between the surfaces of the macrophage and GRC is an important factor in the control mechanism of the attachment to macrophages that preceded ingestion.
\end{abstract}

The electric surface charge of the cells and particles probably has an effect on phagocytosis, especially on the attachment of particles to the cell surface. Many reports have suggested that the mechanism of phagocytosis is largely related to the electrostatic property of the surface of the phagocytic cell and phagocytized particles $(4,8,11,13,15-18,22,23)$. Furthermore, enhancement of phagocytic activity has been reported with polycationic compounds $(4,11,15,18)$. The polyelectrolytes in the medium change the electrostatic property of the cells and the particles. The present experiment with peritoneal macrophages was designed to examine the influence of the cell and particle surface charge on phagocytosis. The results showed inhibition of phagocytosis by an electrostatic repulsive force between macrophages and glutaraldehyde-treated red cells.

\section{MATERIALS AND METHODS}

Preparation of macrophages. Peritoneal macrophages of Wistar strain rats, weighing $250-300 \mathrm{~g}$, were used as phagocytic cells. The cells were harvested from the peritoneal fluid of animals treated with intraperitoneal injection of $5 \%$ starch suspension 4 days previously by the Nomoto's method (12) modified by authors (11). The cells were washed twice with cold phosphate buffered saline (PBS) or PBS adjusted to one-tenth ionic strength with an isotonic 
aqueous solution of sucrose (1/10 PBS) and suspended in these solutions. The suspension contained $10^{7} \mathrm{cells} / \mathrm{ml}$ and macrophages constituted more than $85 \%$ of cells.

Preparation of glutaraldehyde-treated erythrocytes (GRCs). Fresh sheep red cells were used. They were washed with PBS and suspended in ten volumes of $0.1 \%$ glutaraldehyde solution in PBS and fixed at $4^{\circ} \mathrm{C}$ for 24 hours with occasional agitation. After fixation the red cells were washed five times with a large volume of PBS or 1/10 PBS by repeated centrifugation and stored at $4{ }^{\circ} \mathrm{C}$. These fixed red cells were used for observations of macrophage phagocytosis.

Polyelectrolytes. Protamine sulfate (NBCo, ICN Pharmaceutical, Inc., Cleveland, U.S.A.) was used as a positive charged polyelectrolyte and chondroitin sulfate (Behringwerke, Germany) was used as a negative charged polyelectrolyte. The reagents were dissolved in PBS and $1 / 10$ PBS, respectively, at a concentration of $10 \mathrm{mg} / \mathrm{ml}$.

Treatment of cells. Peritoneal macrophages and GRCs were incubated at room temperature for $10 \mathrm{~min}$ in the presence of polyelectrolyte solutions at concentrations from $0.01 \mathrm{mg} / \mathrm{ml}$ to $10 \mathrm{mg} / \mathrm{ml}$. In all cases the cell number was adjusted to $10^{7}$ cell $/ \mathrm{ml}$. After incubation the cells were washed with PBS or 1/10 PBS containing no polyelectrolytes by three repeated centrifugations. Macrophage viability was examined by the dye-exclusion test with $0.25 \%$ trypan blue solution.

Measurement of electrophoretic mobility of macrophage and GRC. The electrophoretic mobilities of macrophages and GRCs were measured at $25 \pm 0.5^{\circ} \mathrm{C}$ by the method of Kojima and Maekawa (9) using a Zeiss cell electrophoresis apparatus. The electrophoretic medium was PBS or $1 / 10$ PBS supplemented with $0.25 \mathrm{M}$ sucrose, final $\mathrm{pH} 7.4$, ionic strength 0.15 or 0.015 , respectively, and contained $10^{7} \mathrm{cells} / \mathrm{ml}$. More than 30 cells were examined for each condition.

Measurement of phagocytic activity. Macrophages were incubated with GRCs at $37^{\circ} \mathrm{C}$ or $4^{\circ} \mathrm{C}$ for $30 \mathrm{~min}$ in $35 \times 10 \mathrm{~mm}$ plastic trays containing $2 \mathrm{ml}$ of PBS or 1/10 PBS. The final cell population was $3-5 \times 10^{6}$ macrophage/ml, and the ratio of GRC-to-macrophage was 10:1. After incubation the floating GRCs were removed by washing the macrophage layer with the incubation medium. The macrophages were then fixed with $2 \%$ glutaraldehyde in incubation medium adjusted to $\mathrm{pH} 7.4$ at room temperature for $30 \mathrm{~min}$, stained with Giemsa and air dried. For quantitation, the number of GRCs attached to or ingested by 500 macrophages was determined under a light microscope with oil immersion lens, and the GRC/macrophage ratio was calculated.

\section{RESULTS}

Effects of polyelectrolytes and ionic strength on electrophoretic mobility of macrophages and GRCs. The electrophoretic mobility decreased by incubation of macrophages with protamine sulfate at $0.1 \mathrm{mg} / \mathrm{ml}$ or more, and the mobility dropped to one-

TABLE 1. EFFECTS OF POLYELECTROLYTE CONCENTRATION ON ELECTROPHORETIC MOBILITY OF MACROPHAGES

\begin{tabular}{cccc}
\hline $\begin{array}{c}\text { Treatment } \\
(\mathrm{mg} / \mathrm{ml})\end{array}$ & $\begin{array}{c}\text { Protamine sulfate } \\
(\mu / \mathrm{sec} / \mathrm{V} / \mathrm{cm}) \\
\mathrm{M} \pm \mathrm{SE}\end{array}$ & $\begin{array}{c}\text { Chondroitin sulfate } \\
(\mu / \mathrm{sec} / \mathrm{V} / \mathrm{cm}) \\
\mathrm{M} \pm \mathrm{SE}\end{array}$ & \\
\hline 10 & $-0.154 \pm 0.011$ & $-0.760 \pm 0.037$ & \\
1 & $-0.320 \pm 0.025$ & $-0.584 \pm 0.021$ & \\
0.1 & $-0.403 \pm 0.027$ & $-0.553 \pm 0.020$ & \\
0.01 & $-0.523 \pm 0.013$ & $-0.523 \pm 0.011$ & $-0.516 \pm 0.014$ \\
None & & & - \\
\hline
\end{tabular}

The measurements were made at $25 \pm 0.5^{\circ} \mathrm{C}$ by a Zeiss electrophoresis apparatus. The cell mobilities were calculated in $\mu / \mathrm{sec} / \mathrm{V} / \mathrm{cm}$. At least 30 cells were measured for each determination. 
half the original level at the concentration of $1 \mathrm{mg} / \mathrm{ml}$. Macrophage treatment with chondroitin sulfate concentration of $1 \mathrm{mg} / \mathrm{ml}$ or less induced no detectable change in mobility, but at a concentration of $10 \mathrm{mg} / \mathrm{ml}$ the mobility increased significantly, suggesting that the cells had positively charged residues (Table 1). The macrophages in all cases showed much lower electrophoretic mobility than GRCs (Table 2). The macrophage viability test was performed by the dye-exclusion test and revealed that protamine sulfate treatment at $1 \mathrm{mg} / \mathrm{ml}$ or lower had no toxic effect on the cells, but a toxic effect was found at a concentration of $10 \mathrm{mg} / \mathrm{ml}$ (Table 3). Chondroitin sulfate treatment resulted in no remarkable toxic effect on cells at the concentrations tested.

TABLE 2. EFFECTS OF POLYELECTROLYTES AND IONIC STRENGTH ON ELECTROPHORETIC MOBILITY OF GLUTARALDEHYDE-TREATED RED CELLS AND MACROPHAGES

\begin{tabular}{|c|c|c|c|c|}
\hline \multirow[b]{2}{*}{$\begin{array}{l}\text { Treatment } \\
(1 \mathrm{mg} / \mathrm{ml})\end{array}$} & \multicolumn{2}{|c|}{ Glutaraldehyde-treated red cells } & \multicolumn{2}{|c|}{ Macrophages } \\
\hline & $\begin{array}{c}\text { PBS } \\
(\mu / \mathrm{sec} / \mathrm{V} / \mathrm{cm}) \\
\mathrm{M} \pm \mathrm{SE}\end{array}$ & $\begin{array}{c}1 / 10 \mathrm{PBS} a \\
(\mu / \mathrm{sec} / \mathrm{V} / \mathrm{cm}) \\
\mathrm{M} \pm \mathrm{SE}\end{array}$ & $\begin{array}{c}\text { PBS } \\
(\mu / \mathrm{sec} / \mathrm{V} / \mathrm{cm}) \\
\mathrm{M} \pm \mathrm{SE}\end{array}$ & $\begin{array}{c}1 / 10 \mathrm{PBS} a \\
(\mu / \mathrm{sec} / \mathrm{V} / \mathrm{cm}) \\
\mathrm{M} \pm \mathrm{SE}\end{array}$ \\
\hline $\begin{array}{c}\text { Protamine } \\
\text { sulfate }\end{array}$ & $-0.464 \pm 0.046$ & $-1.605 \pm 0.101$ & $-0.283 \pm 0.031$ & $-0.855 \pm 0.111$ \\
\hline $\begin{array}{l}\text { Chondroitin } \\
\text { sulfate }\end{array}$ & $-0.953 \pm 0.027$ & $-1.931 \pm 0.112$ & $-0.462 \pm 0.056$ & $-1.314 \pm 0.093$ \\
\hline Non-treated & $-0.937 \pm 0.063$ & $-1.923 \pm 0.096$ & $-0.444 \pm 0.042$ & $-1.300 \pm 0.094$ \\
\hline
\end{tabular}

$\bar{a}$ PBS adjusted to one-tenth ionic strength.

Macrophage and GRC measurements were made at $25 \pm 0.5^{\circ} \mathrm{C}$. The cell mobilities were calculated in $\mu / \mathrm{sec} / \mathrm{V} / \mathrm{cm}$. At least 30 cells were measured for each determination.

An increase in the ionic strength of the medium significantly suppressed the surface charge densities of both macrophages and GRCs (Table 2). The electrophoretic mobilities of macrophages and GRCs measured in 1/10 PBS (ionic strength, 0.015) were two or three times faster than in PBS (ionic strength, 0.15).

TABLE 3. VIABILITY OF MACROPHAGES AFTER POLYELECTROLYTE-TREATMENT

\begin{tabular}{|c|c|c|c|}
\hline $\begin{array}{l}\text { Treatment } \\
(\mathrm{mg} / \mathrm{ml})\end{array}$ & $\begin{array}{c}\text { Protamine sulfate } \\
(\%)\end{array}$ & $\begin{array}{c}\text { Chondroitin sulfate } \\
(\%)\end{array}$ & \\
\hline 10 & 53.8 & 94.1 & \\
\hline 1 & 83.4 & 94.3 & \\
\hline 0.1 & 84.8 & 89.8 & \\
\hline 0.01 & 85.4 & 90.2 & \\
\hline None & & & 89.1 \\
\hline
\end{tabular}

The dye-exclusion results are expressed as percentages of viable cells. At least 500 cells were measured for each determination.

Effects of polyelectrolytes and ionic strength on phagocytic activity of macrophages. Treatment of GRCs and macrophages with protamine sulfate resulted in an increase in the number of GRCs attached to and ingested by macrophages. The phagocytic activity was stronger in the GRC-treated group than the macrophage-treated group. The phagocytic promoting effects were marked on the attachment of GRCs to macrophages. The phagocytosis-enchancing effect of protamine sulfate was seen at concentrations of 0.1 to $1 \mathrm{mg} / \mathrm{ml}$, while chondroitin sulfate had little effect on phagocytosis, though some suppression was evident at increased concentrations (Fig. 1). 

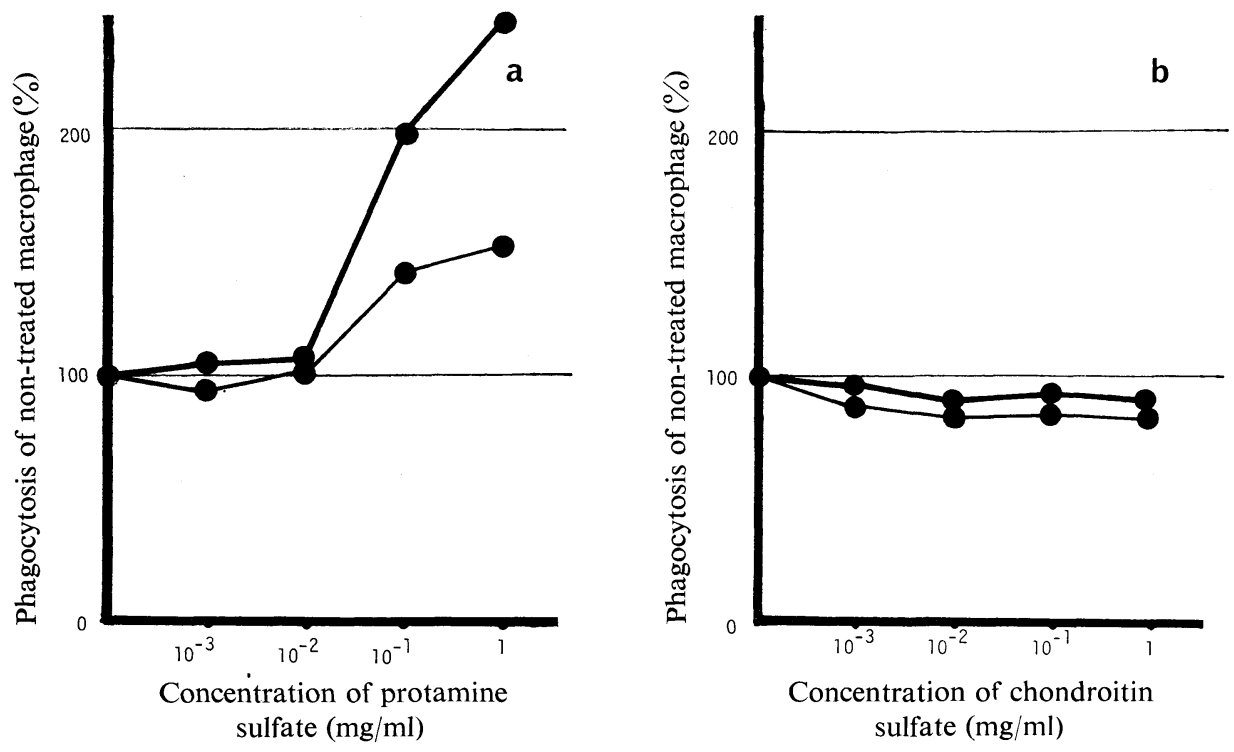

Fig. 1. Dose-response curves for protamine sulfate (Fig. la) and chondroitin sulfate (Fig. 1b) on the rate of attachment (-) and ingestion (-) by polyelectrolytes. Results are expressed as percentages of the nontreated macrophage value.
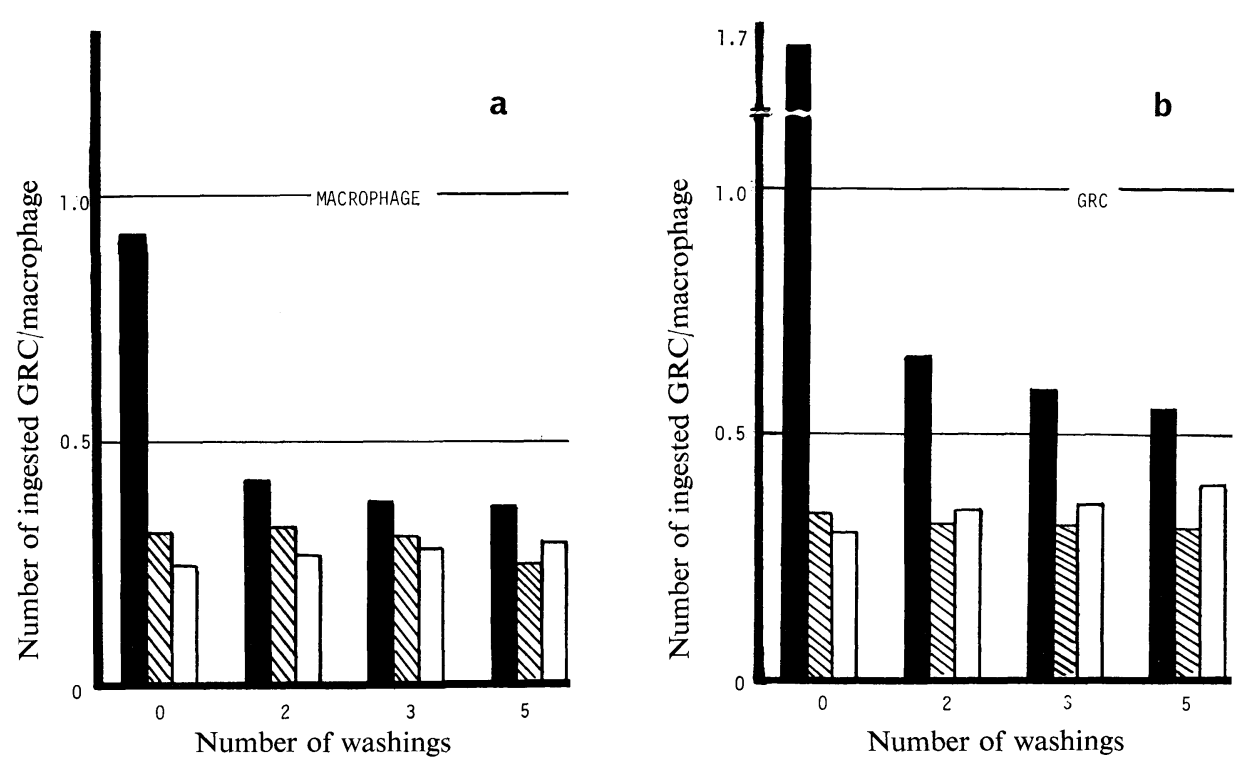

Fig. 2. Phagocytic activity during the course of washing polyelectrolyte-treated macrophages (Fig. 2a) and GRCs (Fig. 2b). Results are expressed as percentages of the value of macrophages or GRCs washed three times in PBS. Macrophages and GRCs were previously treated by polyelectrolytes. $\square$, Protamine sulfate; $\square$, chondroitin sulfate; $\mathbb{Z}$, nontreated. 
Washing with polyelectrolyte-free solution did not diminish the effects of polyelectrolyte treatment, and increased phagocytic activity was observed even after two to five washes. The effect of polyelectrolyte-treatment on the surface charge and phagocytosis was preserved after washings (Fig. 2). The ionic strength of the medium also exerted a marked effect on the phagocytic activity of macrophages that diminished with decreased ionic strength (Fig. 3).
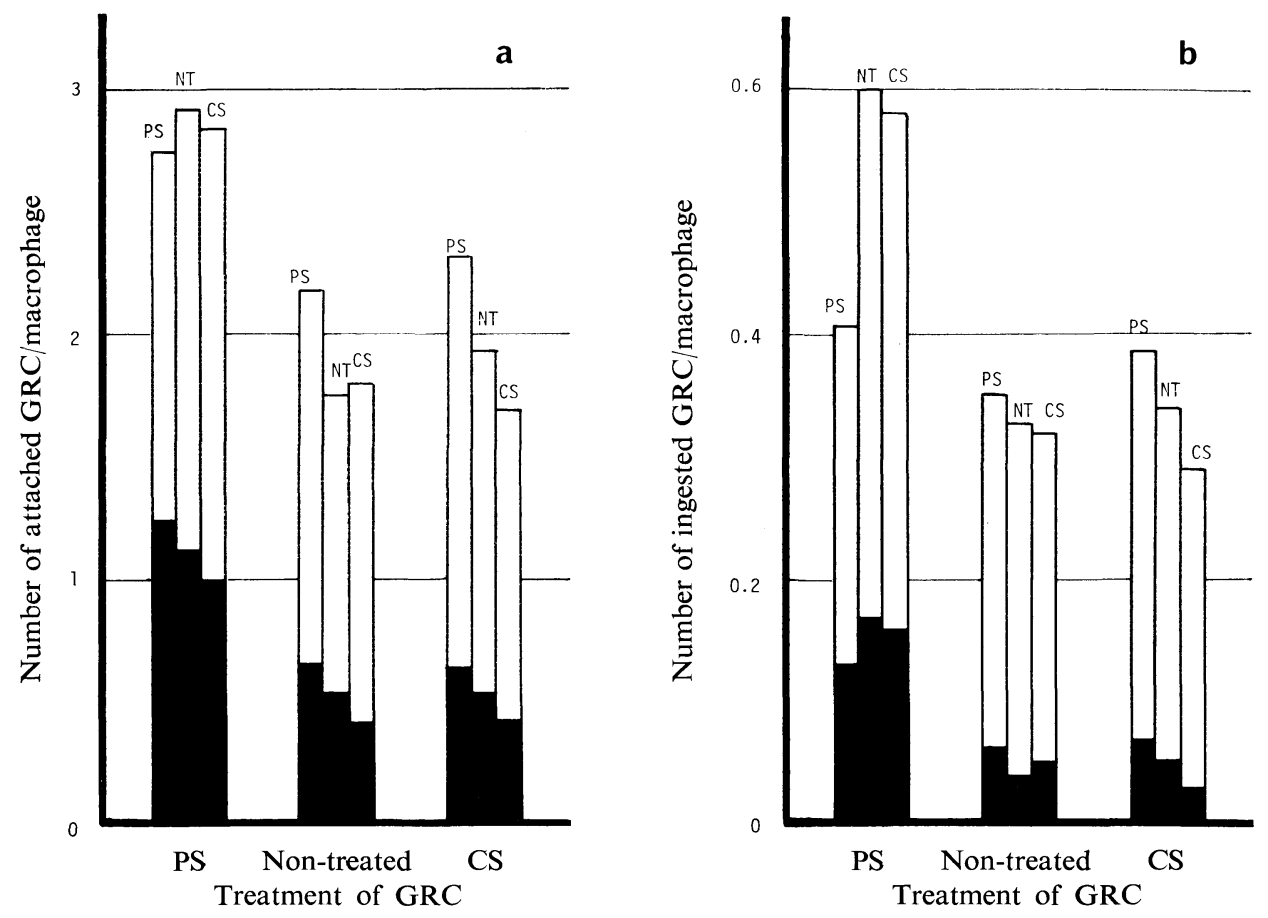

Fig. 3. Comparison of the effect of polyelectrolytes on attachment (Fig. 3a) or ingestion (Fig. 3b) of GRC-to-macrophage. Number of attached and ingested GRC-to-macrophage are plotted against the treatment of GRCs by polyelectrolytes. Macrophages treated with polyelectrolytes (PS, protamine sufate, $1 \mathrm{mg} / \mathrm{ml}$; CS, chondroitin sulfate, $1 \mathrm{mg} / \mathrm{ml} ; \mathrm{NT}$, non-treated) were incubated in the medium of PBS ( $\square$ ) or PBS adjusted to one-tenth ionic strength ( $\square$ ) with polyelectrolytetreated or non-treated GRCs for $30 \mathrm{~min}$ at $37^{\circ} \mathrm{C}$.

Correlation of phagocytic activity of macrophages with electrophoretic mobility. The macrophage-GRC-attachment and GRC-ingestion values in the different experimental conditions $(\mathrm{Y})$ were plotted against the product of the respective values of the electrophoretic mobility of macrophages and GRCs (X) (Fig. 4). The phagocytic activity of macrophages was significantly stimulated with decreased electrophoretic mobilities. The regression line for GRC-attachment and GRC-ingestion of macrophage was $\mathrm{Y}=$ $2.50-0.842 \mathrm{X}$ and $\mathrm{Y}=0.444-0.166 \mathrm{X}$, respectively. Application of the Student's t-test yielded a probability value of less than 0.005 between the two groups (14). It is evident that the macrophage activity decreased linearly with the increased product of negative charge densities on the surfaces of both GRCs and macrophages. The results also 


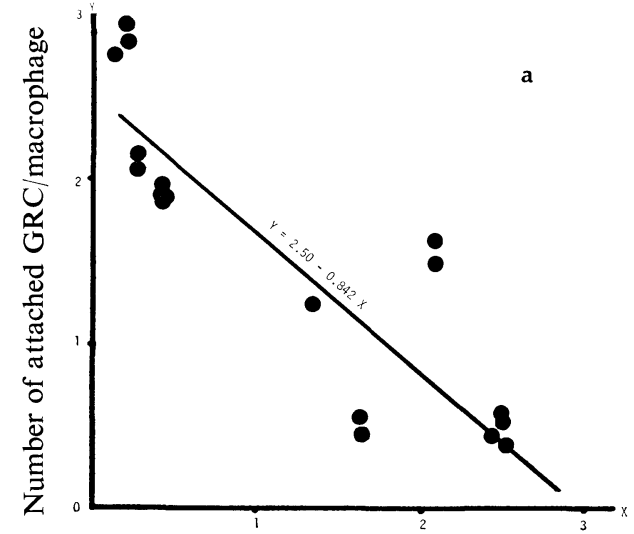

Product of values of electrophoretic mobility in macrophage and $\operatorname{GRC}(\mu / \mathrm{sec} / \mathrm{v} / \mathrm{cm})^{2}$

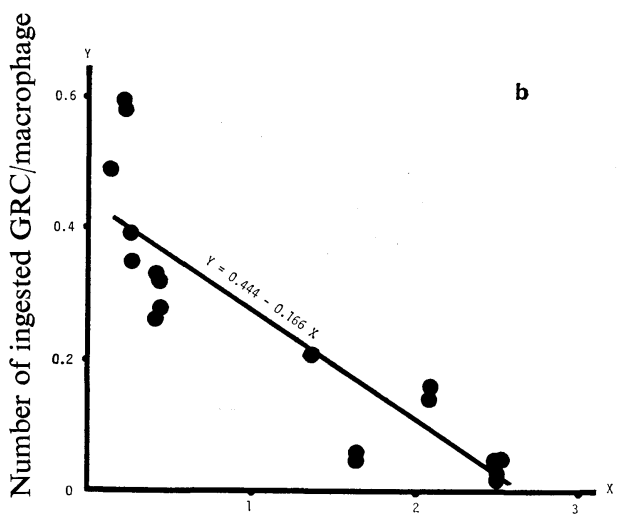

Product of values of electrophoretic mobility in macrophage and $\operatorname{GRC}(\mu / \mathrm{sec} / \mathrm{v} / \mathrm{cm})^{2}$

Fig. 4. Comparison of electrophoretic mobilities of macrophages on attachment (Fig. 4a) and ingestion (Fig. 4b) of GRCs. Number of attached and ingested GRC-to-macrophage are plotted against the product of values of their mobilities. The regression equation for GRC-attachment and GRC-ingestion of macrophage was $Y=2.50-0.842 X$ and $Y=0.444-0.166 X$, respectively.

showed that the attachment ratio of GRC-to-macrophage was more than five times the ingestion ratio of GRC-to-macrophage.

\section{DISCUSSION}

A negatively charged surface layer consisting of ionized carboxyl residues has been detected on many cells $(1,2,6,10,22)$. The surfaces of various types of mammalian cells may also have ionizable amino and phosphate residues from plasma membrane components $(10,20)$. The macrophage surface negativity increased by chondroitin sulfate treatment had less net negative-charge than GRCs, probably due to the many amino residues on the surface. It has been reported that attachment of particles to the cell surface is regulated not only by electrostatic forces $(8,17,23)$ but by various other forces, such as the van der Waals force $(3,23)$ and the force between hydrophilic surfaces (19). All these forces may contribute in some manner, but the electrostatic force may participate as the initial attractive or repulsive force between the phagocyte and particles, followed by the van der Waals force and other forces, because the electrostatic force is more effective over distances than other forces (23).

In the Helmholtz-Smoluchowski equation $(\mu=\sigma / \mathrm{kn})$, electrophoretic mobility $(\mu)$ is related to charge density $(\sigma)$ at the periphery, the Debye-Hückel parameter $(1 / \mathrm{k})$ and the viscosity (n) of the suspension medium (21). The viscosity of PBS and $1 / 10$ PBS was practically the same, since sucrose was the similar supplement of both media. It is therefore assumed that changes in electrophoretic mobility are due entirely to changes in charge density at the cell surface. The present results indicated that the macrophage has lower electrophoretic mobility than other non-phagocytic cells (11), and that protamine sulfate treatment of the macrophage decreases the electrophoretic mobility to a great degree, and consequently increases phagocytic activity. Moreover, attachment was more intimate to surface charge density than ingestion. A theoretical 
analysis of these results clearly showed that attachment and ingestion decreased linearly with increased negative surface values of macrophages and GRCs. It may be said that Coulomb's electrostatic force due to surface charge contributes to the repulsive barrier between macrophages and GRCs during the process of attachment.

Little information exists on the mechanisms of mutual attachment in phagocytosis. Some investigators reported a reduction in the electrophoretic mobility of macrophages from immunized animals to specific antigen $(5,7)$. A problem to investigate in the future is the role of the electric surface charge in relation to specific receptor(s) in phagocytosis.

\section{REFERENCES}

1. Bangham, A.D., B.A. Pethica and G.V.F. Seaman. The charged group at the interface of some blood cells. Biochem. J. 69, 12-19, 1958

2. Cook, G.M.W., D.H. Heard and G.V.F. Seaman. The electrokinetic characterization of the Ehrlich ascites carcinoma cells. Exp. Cell Res.28, 27-39, 1962

3. CurTIS, A.S.D. The measurement of cell adhesiveness by an absolute method. J. Embryol. Exp. Morphol. 22, 305-325, 1969

4. de Varies, A., J. Salgo, Y. Matoth, A. Nevo and E. Katchalski. Effect of basic polyamino acids on phagocytosis in vitro. Arch. Int. Pharmacodyn. Ther. 104, 1-10, 1955

5. DienGDOH, J.V. and J.L. TURK. Electrophoretic mobility of guinea pig peritoneal exudate cells in hypersensitivity reaction. Int. Arch. Allergy Appl. Immurol. 34, 297-302, 1968

6. Gasic, G.J., L. BerwicK and M. Sorrentino. Positive and negative colloidal iron as cell surface electron stains. Lab. Invest. 18, 63-71, 1968

7. Hartveit, F., D.B. Carter and J.N. Mehrishi. Changes in the electrophoretic mobility of mouse lymphocytes, thymocytes, macrophages and tumor cells following immunization. $B r . J$. Exp. Path. 49, 634-647, 1968

8. JANDL, J.H. and R.L. Simmons. The agglutination and sensitization of red cells by metallic cations; interactions between multivalent metals and the red-cell membrane. $\mathrm{Br}$. J. Haematol. 3, 19-38, 1957

9. Kojima, K. and A. Maekawa. Difference in electrokinetic change of cells between two cell types of ascites hepatoma after removal of siliac acid. Cancer Res. 30, 2858-2862, 1970

10. Langley, O.K. and E.J. Ambrose. The linkage of sialic acid in the Ehrlich ascites-carcinoma cell surface membrane. Biochem. J. 102, 367-372, 1967

11. Nagura, H., J. Asai, Y. Katsumata and K. Kojima. Role of electric surface charge of cell membrane in phagocytosis. Acta Path. Jpn. 23, 279-290, 1973

12. Nомото, K. Isolation of macrophages. In Textbook of Immunology., ed. Japanese Society of Immunology, published by Japanese Society of Immunology, Tokyo and Kanazawa, pp 158159, 1970 (in Japanese)

13. REYSER, H.J.P. Uptake of protein by mammalian cells; an underdeveloped area. The penetration of foreign protein into mammalian cells can be measured and their functions explored. Science 159, 390-396, 1968

14. Sakuma, A. Method for Biological Assay. Tokyo Univ. Press, Tokyo, pp, 110, 1974 (in Japanese)

15. Seno, S., T. Кімото and N. IтоH. Uptake of metal colloid particles by Ehrlich ascites tumor cell induced by histone. In Hemorrheology (Proceeding of the First Conference, Reykjavik, 1966), Pergamon Press, Oxford, pp. 565-568, 1968

16. Seno, S., A. Tanaka, M. Urata, K. Hirata, H. Nakatsuka and S. Yamamoto. Phagocytic response of rat liver capillary endothelial cells and Kupffer cells to positive and negative charged iron colloid particles. Cell Struct. Funct. 1, 119-127, 1975

17. Skutelsky, E. and D. Danon. Reduction in surface charge as an explanation of the recognition by macrophages of nuclei expelled from normoblasts. J. Cell Biol. 43, 8-15, 1969

18. Томіока, S. Effects of dextran sulfate on phagocytosis by leucocytes. J. Jpn. Soc. RES 12, 4753,1972 (in Japanese)

19. Van Oss, C.J. and C.F. Gillman. Phagocytosis as a surface phenomenon. 1. Contact angles and 
phagocytosis of non-opsonized bacteria. J. Reticuloendothel. Soc. 12, 283-292, 1972

20. Wallach, D.F.H. Generalized membrane defects in cancer. New Eng. J. Med. 280, 761-767, 1969

21. Weiss, L. Studies on cell deformability. I. Effects of surface charge. J. Cell Biol. 26, 735-739, 1965

22. Weiss, L., E. MAYHEW and K. Ulrich. The effect of neuraminidase on the phagocytic process in human monocytes. Lab. Invest. 15, 1304-1309, 1966

23. Yokomura, E., Y. Shimizu and S, Seno. Studies on the mechanism of phagocytosis. II. Analysis of the adhesion phase. Jpn. J. Med. Sci. Biol. 27, 191-204, 1974

(Received for publication, April 5, 1976) 